JURNAL GIZI DAN DIETETIK INDONESIA

Vol. 3, No. 3, September 2015: 131-138

\title{
Faktor yang berhubungan dengan preferensi konsumen street food pada mahasiswa Universitas Gadjah Mada
}

\section{Factors related to street food consumer preferences of Gadjah Mada University students}

\author{
Endah Budi Permana $P^{1}$, Sumarni², Fatma Zuhrotun Nisa ${ }^{3}$
}

\begin{abstract}
Background: Habits and preferences influence the street food consumption. Consuming of foods that are high in fat, protein, and carbohydrate could increase the risk to suffered from coronary heart diseases, high blood pressure, diabetes mellitus, and stroke. More than $90 \%$ diseases that occurs in human were caused by food contamination of microorganisms, likes typhus and hepatitis $A$.

Objectives: To analyze factors related to street food consumer preferences of Universitas Gadjah Mada's students.

Methods: This was an observational research with cross sectional design. Samples were 96 UGM's undergraduate students of the year 2012 taken by cluster sampling. Datas were obtained by interview using questionnaire consumer preferences of street food and the individual and food characteristics. Data were then analysed by statistical analysis using correlation test (contingency coefficient and Spearman) and multivariate analysis using logistic regression.

Results: There was correlation between sex (RR:1.60, $p=0.012)$, income (RR:1.36, $p=0.017)$ and food prices (RR:0.52, $p=0.001)$ with preference of street food meal. There was correlation between knowledge about nutrition $(R R: 27.75, p=0.000)$ and hygiene and sanitation $(R R: 1.25, p=0.000)$ with preference of street food on fruit group at Universitas Gadjah Mada's students.

Conclusions: Sex, income, and food prices related to preference of street food on meal. Knowledge about nutrition and hygiene sanitation related to preference of fruit group street food of Universitas Gadjah Mada's students.
\end{abstract}

KEYWORDS: food preference, consumer, street food, university students

\begin{abstract}
ABSTRAK
Latar belakang: Kebiasaan dan preferensi seseorang akan sangat mempengaruhi konsumsi street food. Mengonsumsi makanan tinggi lemak, protein, dan karbohidrat dapat meningkatkan risiko terserang penyakit jantung koroner, tekanan darah tinggi, diabetes mellitus, dan stroke. Lebih dari $90 \%$ penyakit yang terjadi pada manusia disebabkan oleh kontaminasi mikroorganisme melalui makanan seperti penyakit tifus dan hepatitis $A$.

Tujuan: Menganalisis faktor-faktor yang berhubungan dengan preferensi konsumen street food pada mahasiswa Universitas Gadjah Mada.

Metode: Jenis penelitian observasional dengan rancangan cross sectional. Sampel penelitian sebesar 96 orang mahasiswa S1 Universitas Gadjah Mada angkatan 2012 yang diambil secara cluster sampling. Data diperoleh dengan wawancara menggunakan kuesioner preferensi konsumen street food, karakteristik individu, dan makanan.Analisis bivariat menggunakan uji korelasi yaitu koefisien kontingensi dan Spearman, sedangkan analisis multivariat menggunakan regresi logistik.

Hasil: Hasil analisis menunjukkan bahwa jenis kelamin (RR:1,60, $p=0,012$ ), pendapatan $R R: 1,36, p=0,017$ ), dan harga makanan (RR:0,52, $p=0,001)$ merupakan faktor yang berhubungan dengan preferensi konsumen street food kelompok menu utama (RR:27,75, $p=0,000)$, sedangkan pengetahuan gizi dan higiene sanitasi
\end{abstract}

\footnotetext{
${ }^{1}$ Magister Gizi dan Kesehatan, Fakultas Kedokteran UGM, Jl. Farmako, Sekip Utara, Yogyakarta, e-mail: endah.budi92@gmail.com ${ }^{2}$ Bagian Jiwa RSUP Dr. Sarjito, Jl. Kesehatan Yogyakarta 55281

${ }^{3}$ Program Studi Gizi Kesehatan, Fakultas Kedokteran UGM, JI. Farmako Sekip Utara, Yogyakarta
} 
makanan (RR:1,25, $p=0,000)$ merupakan faktor yang berhubungan dengan preferensi konsumen street food kelompok buah-buahan pada mahasiswa Universitas Gadjah Mada.

Kesimpulan: Jenis kelamin, pendapatan, dan harga makanan berhubungan dengan preferensi konsumen street food kelompok menu utama. Pengetahuan gizi dan higiene sanitasi berhubungan dengan preferensi konsumen street food kelompok buah-buahan pada mahasiswa Universitas Gadjah Mada.

KATA KUNCI: preferensi makan, konsumen, street food, mahasiswa

\section{PENDAHULUAN}

Konsumsimakanan yang terus bertambah mengakibatkan semakin berkembangnya usaha kuliner yang menjual makanan di pinggir jalan (street food). Kemudahan mengakses street food membuat mahasiswa memilih untuk mengonsumsi makanan ini. Tiga faktor yang mempengaruhi preferensi makan seseorang yaitu karakteristik individu, makanan, dan lingkungan (1). Konsumsi makanan instan/cepat saji, minuman tinggi gula, kudapan tinggi kalori, dan lemak mengakibatkan konsumsi serat menurun dan konsumsi tinggi kalori meningkat (2). Akibat yang pertama kali muncul apabila salah dalam memilih makanan yaitu overweight yang berlanjut pada obesitas. Obesitas tidak hanya mengganggu penampilan fisik seseorang, tetapi juga berisiko lebih besar untuk terserang penyakit jantung koroner, tekanan darah tinggi, diabetes mellitus, dan stroke (3). Sebanyak $57 \%$ pencari kerja lulusan perguruan tinggi gagal dalam tes kesehatan karena mengidap penyakit kolesterol, jantung, dan diabetes mellitus (4). Lebih dari $90 \%$ penyakit yang terjadi pada manusia disebabkan oleh kontaminasi mikroorganisme melalui makanan (foodborne diseases) seperti penyakit tifus, disentri bakteri, botulism, dan intoksikasi bakteri lainnya, serta hepatitis A dan trichinellosis (5).

Berdasarkan latar belakang masalah tersebut, maka perlu adanya penelitian mengenai faktorfaktor yang berhubungan terhadap preferensi konsumen street food pada mahasiswa Universitas Gadjah Mada, antara lain jenis kelamin, asal daerah, pendapatan, pengetahuan gizi, harga makanan, kualitas makanan, dan higiene sanitasi. Diharapkan dengan mengetahui faktor yang berhubungan dengan preferensi konsumen street food,dapat dijadikan sebagai langkah awal untuk mencari alternatif penyelesaian kasus yang berkaitan dengan gizi dan kesehatan mahasiswa UGM oleh pihak universitas juga pemerintah Kabupaten Sleman, Daerah Istimewa Yogyakarta.

\section{BAHAN DAN METODE}

Jenis penelitian observasional dengan rancangan cross sectional. Populasi penelitian yaitu seluruh mahasiswa di Universitas Gadjah Mada. Sampel sebanyak 96 orang merupakan mahasiswa S1 Universitas Gadjah Mada angkatan 2012 (18 fakultas) yang diambil secara purposive (berdasarkan jenis kelamin), menggunakan teknik cluster sampling. Subjek yang digunakan berusia 18-20 tahun, sehat fisik dan mental (tidak sedang sakit). Sementara itu, subjek akan dieksklusi bila memiliki alergi (berupa gatal-gatal, muntah, atau diare) setelah mengonsumsi makanan tertentu, sedang dalam diet ketat (misal: menurunkan berat badan), memiliki kepercayaan untuk tidak mengonsumsi jenis makanan tertentu, dan sedang menjalankan pola hidup vegan.

Variabel bebas penelitian yaitu jenis kelamin, asal daerah, pendapatan, pengetahuan gizi, harga makanan, kualitas makanan, dan higiene sanitasi. Pengetahuan gizi yang dimaksud dalam penelitian adalah kemampuan responden dalam menjawab pertanyaan mengenai konsep dasar gizi dan akibat yang ditimbulkannya, pemilihan makanan, serta kandungan gizi makanan. Harga makanan adalah nilai tukar (dalam mata uang rupiah) yang biasa dikeluarkan oleh responden untuk mendapatkan street food. Kualitas makanan yaitu segala sesuatu yang ada hubungannya dengan nilai atau mutu makanan, yaitu: flavor (rasa/bau), consistency (konsisten), texture (tekstur makanan), visual appeal (penampilan makanan), nutritional content (kandungan gizi), dan temperature (suhu makanan). Data diperoleh dengan wawancara menggunakan kuesioner karakteristik individu, sedangkan kuesioner pengetahuan gizi 
terdiri dari 20 pertanyaan yang sebelumnya telah diuji validitas dan reliabilitasnya.Sementara itu, harga makanan, kualitas makanan, dan higiene sanitasi diperoleh dengan wawancara menggunakan kuesioner karakteristik makanan.Variabel terikat pada penelitian ini yaitu preferensi konsumen street food. Cara pengukurannya yaitu wawancara menggunakan kuesioner preferensi konsumen street food yang berisi jenis makanan dan frekuensi konsumsinya dari setiap kelompok street food (menu utama, kudapan, minuman, dan buah-buahan).

Pengambilan data dilakukan setelah mendapatkan surat kelaikan etik (ethical clearance) dari Komite Etik Fakultas Kedokteran UGM dengan nomor Ref: KE/ FK/86/EC tahun 2014 dan mendapatkan persetujuan dari calon subjek. Analisis bivariat menggunakan uji korelasi yaitu koefisien kontingensi dan Spearman dengan tingkat kesalahan sebesar $5 \%$ dan $\alpha=0,05$ sedangkan analisis multivariat digunakan regresi logistik. Data dianalisis menggunakan software program STATA versi 12.

\section{HASIL}

\section{Karakteristik individu}

Subjek merupakan mahasiswa S1 UGM angkatan 2012. Dipilinnya angkatan tersebut karena dianggap telah mampu beradaptasi dengan lingkungan dan makanan yang terdapat di sekitar kampus tempat mereka tinggal, dengan perbandingan jumlah laki-laki dan perempuan sama, yaitu $48(50 \%)$ laki-laki dan $48(50 \%)$ perempuan.

Terdapat $25(26,04 \%)$ subjek berasal dari Pulau Sumatera seperti Aceh, Padang, Medan, Bengkulu, Palembang, Bangka Belitung, dan Lampung. Sebanyak 48 (50\%) subjek yang berasal dari Pulau Jawa seperti Jakarta, Jawa Barat, Jawa Tengah, Yogyakarta maupun Jawa Timur. Terdapat $14(14,58 \%)$ subjek berasal dari Pulau Kalimantan yaitu Kalimantan Barat, Kalimantan Selatan, Kalimantan Tengah, dan Kalimantan Timur. Selain ketiga pulau tersebut terdapat $9(9,38 \%)$ subjek berasal dari pulau lainnya di Indonesia seperti Pulau Bali, Sulawesi, dan Nusa Tenggara (Tabel 1).

Sumber pendapatan yang diperoleh subjek berasal dari uang saku orang tua, beasiswa, serta
Tabel 1. Distribusi frekuensi berdasarkan karakteristik individu

\begin{tabular}{lcc}
\hline \multicolumn{1}{c}{ Variabel } & $\mathbf{n}$ & $\%$ \\
\hline $\begin{array}{l}\text { Jenis kelamin } \\
\quad \text { Perempuan }\end{array}$ & 48 & 50,00 \\
$\quad$ Laki-laki & 48 & 50,00 \\
Asal daerah & & \\
$\quad$ Sumatera & 25 & 26,04 \\
$\quad$ Jawa & 48 & 50,00 \\
$\quad$ Kalimantan & 14 & 14,58 \\
$\quad$ Lainnya & 9 & 9,38 \\
Pendapatan & & \\
$\quad$ Rendah ( $\leq$ Rp 1.000.000,-) & 52 & 54,17 \\
$\quad$ Tinggi (>Rp 1.000.000,-) & 44 & 45,83 \\
Pengetahuan gizi & & \\
$\quad$ Kurang (skor $\leq 65 \%)$ & 64 & 66,67 \\
$\quad$ Cukup (skor >65\%) & 32 & 33,33 \\
\hline
\end{tabular}

gaji dari kerja paruh waktu. Terdapat $52(54,17 \%)$ subjek dengan pendapatan rendah dan 44 (45,83\%) subjek dengan pendapatan tinggi. Sebagian besar subjek memiliki pengetahuan gizi yang kurang yaitu $64(66,67 \%)$ orang, sedangkan $32(33,33 \%)$ orang lainnya memiliki pengetahuan gizi yang cukup.

\section{Karakteristik makanan}

Karakteristik makanan merupakan faktor yang diperhatikan oleh seseorang sebelum mengonsumsi street food. Karakteristik makanan pada penelitian ini meliputi harga, kualitas makanan, serta higiene dan sanitasi.

Berdasarkan Tabel 2, diketahui bahwa subjek mengonsumsi street food dengan harga yang murah, baik pada kelompok menu utama $(57,29 \%)$, kudapan $(55,21 \%)$, minuman $(52,08 \%)$, dan buah-buahan (75\%). Apabila ditinjau dari kualitas makanannya, sebanyak $52,08 \%$ subjek menjadikan kualitas makanan yang baik sebagai bahan pertimbangan dalam mengonsumsi street food, sedangkan $47,92 \%$ subjek lainnya memilih tetap mengonsumsi street food dengan kualitas yang cukup baik. Selain harga dan kualitas makanan, faktor lain yang menjadi perhatian yaitu higiene dan sanitasi dari penjamah makanan, lingkungan dan makanan. Sebanyak $25 \%$ subjek memilih mengonsumsi street food dengan higiene dan sanitasi yang baik dan $75 \%$ lainnya memilih tetap mengonsumsi street food dengan higiene dan sanitasi yang cukup baik. 
Tabel 2. Penilaian subjek terhadap kualitas makanan

\begin{tabular}{|c|c|c|}
\hline Variabel & $\mathbf{n}$ & $\%$ \\
\hline \multicolumn{3}{|l|}{ Harga street food } \\
\hline \multicolumn{3}{|l|}{ Menu utama } \\
\hline Murah ( $\leq$ Rp 10.000,-) & 55 & 57,29 \\
\hline Mahal (>Rp 10.000,-) & 41 & 42,71 \\
\hline \multicolumn{3}{|l|}{ Kudapan } \\
\hline Murah (SRp 8.000,-) & 53 & 55,21 \\
\hline Mahal(>Rp 8.000,-) & 43 & 44,79 \\
\hline \multicolumn{3}{|l|}{ Minuman } \\
\hline Murah (sRp 5.000,-) & 50 & 52,08 \\
\hline Mahal(>Rp 5.000,-) & 46 & 47,92 \\
\hline \multicolumn{3}{|l|}{ Buah-buahan } \\
\hline Murah (SRp 5.000,-) & 72 & 75,00 \\
\hline Mahal(>Rp 5.000,-) & 24 & 25,00 \\
\hline \multicolumn{3}{|l|}{ Kualitas makanan } \\
\hline Cukup $(\leq 80 \%)$ & 46 & 47,92 \\
\hline Baik $(>80 \%)$ & 50 & 52,08 \\
\hline \multicolumn{3}{|l|}{ Higiene Sanitasi } \\
\hline Cukup ( $\leq 85 \%)$ & 72 & 75,00 \\
\hline Baik $(>85 \%)$ & 24 & 25,00 \\
\hline
\end{tabular}

\section{Faktor-faktor yang berhubungan dengan preferensi konsumen street food}

Hasil analisis statistik pada Tabel 3 menunjukkan bahwa terdapat hubungan antara jenis kelamin dengan preferensi konsumen street food pada kelompok menu utama $(C=0,20, p=0,042)$.

Tidak terdapat hubungan antara jenis kelamin dengan preferensi konsumen street food kelompok kudapan, minuman, dan buah-buahan pada mahasiswa Universitas Gadjah Mada $(p>0,05)$. Ada hubungan positif antara pendapatan dengan preferensi konsumen street food pada kelompok buah-buahan $(r=0,56, p=0,000)$. Pengetahuan gizi berhubungan negatif dengan preferensi konsumen street food kelompok menu utama $(r=-0,21$, $\mathrm{p}=0,044)$. Subjek dengan tingkat pengetahuan yang tinggi memiliki preferensi yang rendah terhadap konsumsi menu utama,sedangkan pada kelompok buah-buahan ada hubungan positif antara pengetahuan gizi dengan preferensi konsumen street food pada kelompok buah-buahan $(r=0,81 ; p=0,000)$. Pada kelompok kudapan dan minuman, tidak ada hubungan yang signifikan antara pengetahuan gizi dengan preferensi konsumen $(p>0,05)$ (Tabel 3$)$.

Hasil analisis statistik pada Tabel 4 menunjukkan adanya hubungan negatif antara harga makanan dengan preferensi konsumen street food kelompok menu utama $(r=0,23, p=0,027)$. Namun demikian, pada preferensi konsumen street food kelompok kudapan, minuman, dan buahbuahan menunjukkan tidak ada hubungan $(p>0,05)$. Berdasarkan hasil penelitian, ada hubungan negatif antara higiene dan sanitasi dengan preferensi konsumen street food kelompok.

Tabel 3. Hubungan karakteristik individu dengan preferensi konsumen street food

\begin{tabular}{lcccccccc}
\hline \multirow{2}{*}{$\begin{array}{c}\text { Preferensi konsumen } \\
\text { street Food }\end{array}$} & \multicolumn{2}{c}{ Jenis kelamin } & \multicolumn{2}{c}{ Asal daerah } & \multicolumn{2}{c}{ Pendapatan } & \multicolumn{2}{c}{ Pengetahuan gizi } \\
\cline { 2 - 9 } & $\mathbf{C}$ & $\mathbf{p}$ & $\mathbf{C}$ & $\mathbf{p}$ & $\mathbf{r}$ & $\mathbf{p}$ & $\mathbf{r}$ & $\mathbf{p}$ \\
\hline Menu Utama & 0,20 & $0,042^{*}$ & 0,13 & 0,281 & $-0,16$ & 0,111 & $-0,21$ & $0,044^{*}$ \\
Kudapan & 0,08 & 0,419 & 0,13 & 0,261 & 0,04 & 0,686 & 0,13 & 0,198 \\
Minuman & 0,02 & 0,840 & 0,27 & 0,622 & 0,06 & 0,533 & 0,03 & 0,776 \\
Buah-buahan & 0,18 & 0,074 & 0,29 & 0,793 & 0,56 & $0,000^{*}$ & 0,81 & $0,000^{*}$ \\
\hline
\end{tabular}

$\mathrm{C}=$ Uji korelasi koefisien kontingensi

$r=$ Uji korelasi Spearman

* Signifikan $(p<0,05)$

Tabel 4. Hubungan karakteristik makanan dengan preferensi konsumen street food

\begin{tabular}{lcccccc}
\hline \multirow{2}{*}{$\begin{array}{c}\text { Preferensi Konsumen } \\
\text { street food }\end{array}$} & \multicolumn{2}{c}{ Harga makanan } & \multicolumn{2}{c}{ Kualitas makanan } & \multicolumn{2}{c}{ Higiene sanitasi } \\
\cline { 2 - 7 } & $\mathbf{r}$ & $\mathbf{p}$ & $\mathbf{r}$ & $\mathbf{p}$ & $\mathbf{r}$ & $\mathbf{p}$ \\
\hline Menu utama & $-0,23$ & $0,027^{*}$ & $-0,04$ & 0,674 & 0,12 & 0,243 \\
Kudapan & $-0,10$ & 0,310 & 0,17 & 0,104 & 0,00 & 1,000 \\
Minuman & $-0,10$ & 0,316 & $-0,15$ & 0,153 & $-0,06$ & 0,560 \\
Buah-buahan & $-0,00$ & 1,000 & $-0,12$ & 0,250 & $-0,21$ & $0,038^{*}$ \\
\hline
\end{tabular}

Keterangan:

$r=$ Uji korelasi Spearman, $\left.{ }^{*}\right)$ Signifikan $(p<0,05)$ 


\section{Analisis multivariat}

Berdasarkan hasil analisis multivariat pada Tabel 5, model terbaik yang dipilih berdasarkan nilai Bayesian Information Criterion (BIC) dan variabel yang signifikan pada kelompok menu utama adalah model $3(p<0,05)$. Jenis kelamin (RR:1,60, $p=0,012)$, dan harga makanan (RR:0,52, $p=0,001)$ berhubungan dengan preferensi konsumen street food pada mahasiswa Universitas Gadjah Mada.

Pada kelompok buah-buahan, model terbaik adalah model 3.Diketahui bahwa pengetahuan gizi dan higiene sanitasi mempengaruhi hubungan preferensi konsumen street food kelompok menu utama pada mahasiswa Universitas Gadjah Mada. Kekuatan hubungan dapat dilihat dari besarnya nilai RR. Nilai RR paling besar yaitu pada variabel pengetahuan gizi (RR:27,75).

\section{BAHASAN}

Faktor-faktor yang berhubungan dengan preferensi konsumen street food

Faktor-faktor yang mempengaruhi food preference yaitu jenis kelamin, asal daerah, pendapatan, pengetahuan gizi, harga makanan,dan kualitas makanan (6). Tiga faktor yang mempengaruhi preferensi makan seseorang yaitu karakteristik individu, makanan, dan lingkungan (1).

Tabel 3 menunjukkan bahwa terdapat hubungan antara jenis kelamin dengan preferensi konsumen street food pada kelompok menu utama $(C=0,20, p=0,042)$.Laki-laki lebih sering mengonsumsi street food daripada perempuan. Berdasarkan hasil wawancara, diketahui bahwa laki-laki tidak bisa memasak dan tidak ada waktu untuk menyediakan makanan sehingga subjek lebih memilih untuk mengonsumsi street food. Namun demikian, tidak terdapat hubungan antara jenis kelamin dengan preferensi konsumen street food kelompok kudapan, minuman, dan buah-buahan $(p>0,05)$. Hal ini disebabkan subjek merupakan mahasiswa yang memiliki kesibukan di luar rumah, sehingga mereka memilih untuk mengonsumsi street food. Selain karena biaya yang dikeluarkan relatif lebih murah, street food juga memiliki banyak variasi yang dapat dinikmati (7).

Pada penelitian ini, terdapat perbedaan jenis makanan yang dikonsumsi laki-laki dengan perempuan. Laki-laki memilih mengonsumsi

Tabel 5. Analisis multivariat faktor-faktor yang berhubungan dengan preferensi konsumen street food

\begin{tabular}{|c|c|c|c|c|c|c|}
\hline \multirow[b]{2}{*}{ Variabel } & \multicolumn{3}{|c|}{ Menu utama } & \multicolumn{3}{|c|}{ Buah-buahan } \\
\hline & $\begin{array}{l}\text { Model } 1 \\
\text { RR } \\
(95 \% \mathrm{Cl}) \\
\text { p }\end{array}$ & $\begin{array}{c}\text { Model } 2 \\
\text { RR } \\
(95 \% \mathrm{Cl}) \\
\text { p }\end{array}$ & $\begin{array}{l}\text { Model } 3 \\
\text { RR } \\
(95 \% \mathrm{Cl}) \\
\text { p }\end{array}$ & $\begin{array}{c}\text { Model } 1 \\
\text { RR } \\
(95 \% \mathrm{Cl}) \\
\text { p }\end{array}$ & $\begin{array}{c}\text { Model } 2 \\
\text { RR } \\
(95 \% \mathrm{CI}) \\
\text { p }\end{array}$ & $\begin{array}{c}\text { Model } 3 \\
\text { RR } \\
(95 \% \mathrm{Cl}) \\
\text { p }\end{array}$ \\
\hline $\begin{array}{l}\text { Jenis kelamin } \\
\text { Laki-laki } \\
\text { Perempuan }\end{array}$ & $\begin{array}{c}1,58 \\
(1,10-2,27) \\
0,013^{\star}\end{array}$ & $\begin{array}{c}10,49 \\
(1,73-63,67) \\
0,011^{*}\end{array}$ & $\begin{array}{c}1,60 \\
(1,11-2,31) \\
0,012^{*}\end{array}$ & $\begin{array}{c}0,81 \\
(0,56-1,16) \\
0,255\end{array}$ & & \\
\hline $\begin{array}{l}\text { Pendapatan } \\
\text { Rendah } \\
\text { Tinggi }\end{array}$ & $\begin{array}{c}1,41 \\
(1,13-1,75) \\
0,002^{*}\end{array}$ & $\begin{array}{c}0,71 \\
(0,16-3,01) \\
0,635\end{array}$ & $\begin{array}{c}1,36 \\
(1,05-1,75) \\
0,017^{*}\end{array}$ & $\begin{array}{c}1,57 \\
(1,09-2,25) \\
0,014^{\star}\end{array}$ & $\begin{array}{c}1,82 \\
(0,94-3,51) \\
0,635\end{array}$ & \\
\hline $\begin{array}{l}\text { Pengetahuan gizi } \\
\text { Kurang } \\
\text { Cukup }\end{array}$ & $\begin{array}{c}0,73 \\
(0,46-1,16) \\
0,185\end{array}$ & & & $\begin{array}{c}24,76 \\
(6,19-99,01) \\
0,000^{\star}\end{array}$ & $\begin{array}{c}23,25 \\
(5,53-97,65) \\
0,000^{*}\end{array}$ & $\begin{array}{c}27,75 \\
(7,05-109,25) \\
0,00 *^{*}\end{array}$ \\
\hline $\begin{array}{l}\text { Harga makanan } \\
\text { Murah } \\
\text { Mahal }\end{array}$ & $\begin{array}{c}0,58 \\
(0,37-0,90) \\
0,015^{\star}\end{array}$ & $\begin{array}{c}11,69 \\
(3,06-44,75) \\
0,000^{*}\end{array}$ & $\begin{array}{c}0,52 \\
(0,34-0,77) \\
0,001^{*}\end{array}$ & & & \\
\hline $\begin{array}{l}\text { Higiene sanitasi } \\
\text { Cukup } \\
\text { Baik }\end{array}$ & $\begin{array}{c}1,03 \\
(1,032-1,033) \\
0,000^{*}\end{array}$ & $\begin{array}{c}1,11 \\
(0,83-1,48) \\
0,482\end{array}$ & & $\begin{array}{c}1,94 \\
(1,39-2,71) \\
0,000^{\star}\end{array}$ & $\begin{array}{c}1,87 \\
(1,59-2,19) \\
0,000^{*}\end{array}$ & $\begin{array}{c}1,25 \\
(1,04-50) \\
0,000^{*}\end{array}$ \\
\hline $\begin{array}{l}\text { Bayesian information } \\
\text { criterion(BIC) }\end{array}$ & $-289,235$ & $-292,525$ & $-296,756$ & $-371,219$ & $-374,913$ & $-376,781$ \\
\hline
\end{tabular}

* Signifikan $(p<0,05)$ 
nasi goreng, sementara perempuan memilih mengonsumsi pecel. Jenis kelamin berperan penting sebagai penentu pemilihan makanan pada mahasiswa dan menentukan jenis makanan yang dimakan tergolong sehat atau tidak (8).

Tidak ada hubungan yang signifikan antara asal daerah dengan preferensi konsumen street food kelompok menu utama, kudapan, minuman, dan buah-buahan $(p>0,05)$ (Tabel 3). Tidak ada perbedaan signifikan antarkelompok etnis (Afrika-Amerika dan Amerika-Eropa) terhadap kelompok makanan favorit mereka (9). Tidak adanya hubungan antara asal daerah dengan preferensi konsumen street food dapat disebabkan subjek yang merupakan mahasiswa memiliki tingkat pendidikan yang tinggi dengan pendapatan yang cukup tinggi, sehingga memiliki akses yang lebih tinggi untuk memilih makanan yang disukainya dan tidak selalu makanan yang sesuai dengan budaya/daerah asal subjek. Selain itu, subjek yang berasal dari berbagai pulau di Indonesia telah mampu beradaptasi dengan makanan yang dijual di Yogyakarta. Jenis makanan yang dijual di pinggir jalan juga sudah beraneka ragam dan merupakan makanan yang banyak ditemukan hampir di setiap provinsi di Indonesia.

Pendapatan individu merupakan salah satu faktor yang mempengaruhi preferensi seseorang terhadap pemilihan suatu produk pangan (6). Tidak ada hubungan antara pendapatan dengan preferensi konsumen street food kelompok menu utama, kudapan, dan minuman (Tabel 3). Hal ini kemungkinan disebabkan ketiga kelompok street food ini merupakan kebutuhan pangan yang setiap hari wajib dikonsumsi oleh subjek, baik pada makan pagi, makan siang, maupun makan malam, sehingga tidak ada perbedaan antara subjek dengan pendapatan tinggi maupun rendah dengan preferensi konsumen street food pada kelompok ini.

Ada hubungan positif antara pendapatan dengan preferensi konsumen street food pada kelompok buah-buahan $(r=0,56, p=0,000)$ (Tabel 3). Hal ini berarti semakin tinggi pendapatan, maka semakin tinggi preferensi konsumen terhadap buahbuahan. Individu dengan pendapatan yang lebih tinggi memiliki konsumsi buah yang lebih baik (10). Pilihan pangan yang sehat lebih mudah ditemui pada lingkungan dengan pendapatan yang lebih tinggi $(11,12,13,14)$.

Pengetahuan gizi berhubungan negatif dengan preferensi konsumen street food kelompok menu utama $(r=-0,21, p=0,044)$ (Tabel 3). Subjek dengan tingkat pengetahuan yang tinggi memiliki preferensi yang rendah terhadap konsumsi menu utama, sedangkan pada kelompok buah-buahan terdapat hubungan positif antara pengetahuan gizi dengan preferensi $(r=0,81, p=0,000)$. Makin tinggi tingkat pengetahuan gizi, maka makin tinggi pula preferensi konsumen terhadap buah-buahan. Tingkat pengetahuan gizi seseorang berpengaruh terhadap sikap dan perilaku dalam pemilihan makanan yang pada akhirnya berpengaruh kepada keadaan gizi individu yang bersangkutan (15).

Pada kelompok kudapan dan minuman, tidak ada hubungan yang signifikan antara pengetahuan gizi dengan preferensi konsumen $(p>0,05)$ (Tabel 3). Hal ini dapat disebabkan adanya faktor lain yang mempengaruhi preferensi subjek, seperti ketersediaan minuman yang disediakan penjual street food. Berdasarkan hasil wawancara, diketahui bahwa faktor lain yang lebih dominan dibandingkan pengetahuan gizi seperti rasa yang enak dan selera juga menjadi faktor yang mempengaruhi preferensi konsumen street food.

Hasil analisis statistik pada Tabel 4 menunjukkan adanya hubungan negatif antara harga makanan dengan preferensi konsumen street food kelompok menu utama $(r=-0,23$, $p=0,027)$. Semakin murah harga makanan, makin tinggi preferensi konsumen terhadap menu utama. Berdasar hasil wawancara dengan responden, diketahui bahwa soto lebih dipilih karena harganya murah dan mengenyangkan. Berbeda dengan kelompok kudapan, minuman, dan buah-buahan, tidak ada hubungan antara harga makanan dengan preferensi konsumen street food $(p>0,05)$. Harga berpengaruh dalam pemilihan pangan, namun harga sering dikesampingkan oleh pertimbangan prestise, rasa, dan kemudahan dalam penyiapannya, sehingga harga bukanlah faktor utama dalam hal pemilihan pangan (1). 
Kualitas makanan dipengaruhi oleh flavour (rasa), consistency (kemantapan/ ketetapan), texture (tekstur), nutritional content (kandungan gizi), visual appeal (daya penarik lewat ketajaman mata), aromatic appeal (daya penarik lewat bau harum), dan temperature (suhu makanan) (16). Pada penelitian ini, tidak ada hubungan antara kualitas makanan dengan preferensi konsumen street food kelompok menu utama, kudapan, minuman, dan buah-buahan pada mahasiswa Universitas Gadjah Mada $(p>0,05)$ (Tabel 4). Mahasiswa lebih cenderung memilih makanan dengan pertimbangan harga dan rasa dengan kualitas rendah dan kandungan gizi yang lebih sedikit (8).

Sanitasi adalah upaya menyiapkan dan menjual makanan di lingkungan yang bersih oleh pekerja yang sehat, guna mencegah kontaminasi yang dapat menyebabkan foodborne diseases. Higiene adalah upaya penerapan prinsip-prinsip sanitasi dalam melindungi kebersihan dan kesehatan seseorang (17). Tidak ada hubungan antara higiene dan sanitasi dengan preferensi konsumen street food kelompok menu utama, kudapan dan minuman pada mahasiswa Universitas Gadjah Mada ( $p>0,05)$.

Hal ini dapat disebabkan oleh adanya faktor lain dalam memilih makanan jajanan. Makanan jajanan yang disukai oleh responden adalah makanan yang rasanya sesuai selera, terjangkau secara ekonomi (murah), dan tersedia di sekitar tempat tinggal (18). Berbagai lokasi yang tidak higienis seperti tempat-tempat makan dan makanan yang kurang bersih adalah sumber penyebab diare seperti makanan yang dijajakan atau disajikan di pinggir jalan (19). Oleh sebab itu, sebagai konsumen sebaiknya mempertimbangkan higiene maupun sanitasi dari makanan yang akan dikonsumsi.

Berdasarkan hasil penelitian, ada hubungan negatif antara higiene dan sanitasi dengan preferensi konsumen street food kelompok buah-buahan ( $r=-$ $0,21, p=0,038$ ) (Tabel 4). Semakin baik praktik higiene dan sanitasi subjek, makin rendah preferensi konsumen terhadap buah-buahan. Buah merupakan bahan pangan yang dapat langsung dikonsumsi, tanpa melalui proses pengolahan, sehingga higiene dan sanitasi dari buah merupakan faktor penting yang perlu diperhatikan.

\section{Analisis multivariat}

Berdasarkan hasil analisis multivariat pada Tabel 5, model terbaik yang dipilih berdasarkan nilai BIC dan variabel yang signifikan $(p<0,05)$ pada kelompok menu utama adalah model 3 . Jenis kelamin (RR:1,60, $p=0,012$ ), pendapatan (RR:1,36, $p=0,017$ ) dan harga makanan (RR:0,52, $p=0,001$ ) berhubungan dengan preferensi konsumen street food pada mahasiswa Universitas Gadjah Mada. Jenis kelamin berhubungan dengan jenis makananyang dikonsumsi, sedangkan pendapatan berhubungan erat dengan kemampuan seseorang dalam membeli pangan. Subjek dengan pendapatan yang tinggi memiliki akses yang lebih besar untuk mengonsumsi makanan yang diinginkan (9). Makin tinggi pendapatan,akan terjadi peningkatan dalam pemenuhan kebutuhan pangan, karena tidak ada batasan harga makanan yang akan dikonsumsi, sehingga menyebabkan semakin beraneka ragam pula pilihan pangannya (20).

Pada kelompok buah-buahan, model terbaik adalah model 3, diketahui bahwa pengetahuan gizi dan higiene sanitasi mempengaruhi hubungan preferensi konsumen street food kelompok menu utama pada mahasiswa Universitas Gadjah Mada. Kekuatan hubungan dapat dilihat dari besarnya nilai RR. Nilai RR paling besar yaitu pada variabel pengetahuan gizi (RR:27,75). Asupan buah lebih rendah pada individu dengan tingkat pengetahuan yang rendah dibandingkan dengan individu dengan tingkat pengetahuan yang lebih tinggi (21).

\section{KESIMPULAN DAN SARAN}

Ada hubungan antara jenis kelamin, pendapatan dan harga makanan dengan preferensi konsumen street food kelompok menu utama, begitu pula antara pengetahuan gizi dan higiene sanitasi dengan preferensi konsumen street food kelompok buah-buahan pada mahasiswa Universitas Gadjah Mada. Perlu adanya promosi health eating pada mahasiswa baik melalui poster maupun leaflet, perlu adanya peningkatan fasilitas kantin sehingga makanan yang dikonsumsi mahasiswa dapat terkontrol, dan perlu adanya inovasi produk pangan 
yang memiliki kandungan gizi yang tinggi namun harganya terjangkau. Selain itu, perlu juga adanya standardisasi mengenai praktik higiene dan sanitasi penjual makanan selain adanya edukasi kepada pembeli mengenai jenis makanan yang sebaiknya dikonsumsi.

\section{RUJUKAN}

1. Suhardjo. Sosio budaya gizi. Bogor: Departemen Pendidikan dan Kebudayaan Dirjen Pendidikan Tinggi, Pusat Antar Universitas Pangan dan Gizi, IPB, Bogor; 1989.

2. Gibney M, Jiyce T, McCarthy. Correlation between energy from added sugars and frequency of added sugars intake in Irish children, teenagers, and adults. J Nutr. 2008;99(5):1117-26.

3. Purwanti S. Perencanaan mutu untuk penderita kegemukan. Jakarta: Penebar Swadaya; 2002.

4. UGM E. 57\% pencari kerja lulusan PT gagal tes kesehatan [Internet]. 2010 [cited 2013 Nov 13]. Available from: http://ugm.ac.id/en/post/ page id $=2543$

5. Winarno F. Keamanan pangan jilid 2. Bogor: M-Brio Press; 2004.

6. Shepherd R, Sparks. Modelling food choice. Glasgow: Blackie Academic and Profesional; 1994.

7. Huzaynah, Shelly. Analisis perilaku mahasiswa Sarmag Universitas Gunadarma Simatupang dalam pemilihan makan siang [Internet]. 2010. Available from: http://wartawarga.gunadarma. ac.id/2010/07/analisis-perilaku-mahasiswasarmag-universitas-gunadarma-simatupangdalam-pemilihan-makan-siang/

8. Boek, Stacey, Stephanie, Kenny C, Keiko G. Gender and race are significant determinants of students' food choices on a college campus. J Nutr Educ Behav. 2012;44:372-8.

9. Yang, Yongbin, D B, Judd, Suzzanne, Gower, et al. Favorite foods of older adults living in the black belt region of the United States Influences of ethnicity, gender, and education. Appetite. 2013;63:18-23.
10. Irala E, Groth, Johansson, Oltersdorf, Prattala, Martinez G. A systematic review of socioeconomic differences in food habits in Europe: consumption of fruit and vegetables. Eur $\mathrm{J}$ Clin Nutr. 2000;54:706-14.

11. Glanz K, Sallis J, Saelens B, Frank L. Nutrition environment measures survey in stores (NEMS-S): development and evaluation. Am J Prev Med. 2007;32(4):282-9.

12. Moore L V., Diez Roux A V. Associations of neighborhood characteristics with the location and type of food stores. Am J Public Health [Internet]. 2006;96(2):325-31. Available from: http://ajph.aphapublications.org/doi/ abs/10.2105/AJPH.2004.058040

13. Powell L, Auld C, Chaloupka F, O'Malley P, Johnston L. Associations between access to food stores and adolescent body mass index. Am J Prev Med. 2007;33(4):S301-7.

14. Franco M, Roux A, Glass T, Caballero B, Brancati F. Neighborhood characteristics and availability of Healthy Foods in Baltimore. Am J Prev Med. 2008;35(6):561-7.

15. Irawati, Damanhuri, Fachrurozi. Pengetahuan gizi murid SD dan SLTP di Kotamadya Bogor. Bogor: Pusat Penelitian Gizi Bogor; 1995.

16. Marsum W. Restoran dan segala permasalahannya edisi 4. Yogyakarta: Andi Offset; 2005.

17. Marriott N, Gravani RB. Principles of food sanitation fifth edition. New York: Springer Science Bussiness Media, Inc; 2006.

18. Martiani D. Kebiasaan jajan dan preferensi terhadap makanan jajanan pada mahasiswa IPB di Wilayah Dramaga. Institut Pertanian Bogor; 2000.

19. Misnadiarly. Etiologi diare pada turis dan anakanak sekolah di beberapa negara di dunia. Maj Kesehat Masy Indones. 1995;23(2):124-7.

20. Tiyas, Yanni T. Preferensi pangan anak sekolah di Kota Bogor. Institut Pertanian Bogor; 2009.

21. Sharkey J, Horel S. Characteristic of potential spatial access to a variety of fruits and vegetables in a large rural area. National Poverty Center/ Economic Research Service, USDA Conference. 2009. 